\title{
Collateral contamination concomitant to the polonium-210 poisoning of Mr Alexander Litvinenko
}

\author{
John Harrison ${ }^{a, b}$, Tracy Smith ${ }^{a}$, Tim Fell ${ }^{a}$, Jenny Smith ${ }^{a}$, George Ham ${ }^{a}$, \\ Richard Haylock ${ }^{a}$, Alan Hodgson ${ }^{a}$, George Etherington ${ }^{a}$ \\ ${ }^{a}$ Public Health England, Centre for Radiation, Chemical and Environmental Hazards, Chilton, \\ Didcot, Oxon, OX11 ORQ. \\ ${ }^{\mathrm{b}}$ Oxford Brookes University, Faculty of Health and Life Sciences, Oxford, OX3 0BP.
}

\begin{abstract}
Mr Litvinenko died on $23^{\text {rd }}$ November 2006, having been poisoned with polonium-210 on $1^{\text {st }}$ November, with evidence of a previous poisoning attempt during October 2006. Measurements of ${ }^{210} \mathrm{Po}$ in urine samples were made for a large number of people to determine whether they may have been contaminated. In the majority of cases, measured levels were attributable to the presence of ${ }^{210} \mathrm{Po}$ from normal dietary sources. For a small number of cases, elevated levels provided evidence of direct contamination associated with the poisonings. For one individual, while estimated doses were below thresholds for irreversible organ damage, a notably increased risk of cancer can be inferred. The use of the chelating agent, Unithiol, to increase ${ }^{210} \mathrm{Po}$ excretion in this case was only moderately effective in reducing doses received.
\end{abstract}

\section{Introduction}

Mr Alexander Litvinenko died on $23^{\text {rd }}$ November 2006, following poisoning with polonium-210 on $1^{\text {st }}$ November. The case has been the subject of a criminal investigation and a public inquiry chaired by Sir Robert Owen that reported on $21^{\text {st }}$ January 2016 (www.litvinenkoinquiry.org). The clinical case history has recently been published (Nathwani et al 2016), with separate publication of associated details of assessments of intake of ${ }^{210} \mathrm{Po}$, organ doses and consequent rapid decline in physiological function leading to death (Harrison et al 2017). The results presented by Harrison et al (2017) include evidence of a previous poisoning attempt during October 2006. This paper considers the ${ }^{210} \mathrm{Po}$ contamination of other individuals, principally on the basis of measurements on urine samples.

Polonium-210 is an alpha particle (5.3 MeV) emitting radionuclide with a half-life of 138 days. It is a naturally-occurring radionuclide, present in our diets, body tissues and excreta as a member of the uranium-238 decay chain. Dietary intake varies substantially so that urinary excretion is also variable (Hodgson 2017). Interpretation of urine measurements to assess the probability of contamination from artificial sources must therefore take account of natural levels and their variability.

Polonium-210 contamination was found at the two London hospitals responsible for the care of Mr Litvinenko from $3^{\text {rd }}$ November 2006, raising concerns that hospital staff may have become contaminated. The police investigation identified a number of contaminated locations, including parts of several hotels, restaurants, and office buildings. Twenty-four hour urine samples were taken from a large number of people judged to be at risk of contamination (over 800 ) in order to determine the extent of 
any contamination (Bailey et al 2008, 2010, Maguire et al 2010). International followup of persons potentially exposed was reported by Shaw et al (2010).

The Litvinenko Inquiry was provided with reports on two additional contaminated individuals by an Expert Commission of the Federal Medical and Biological Agency (FMBA) of the Russian Federation. These reports provide measurements and interpretation for individuals referred to here as $X$ (COM00181001) and $Y$ (COM00182001) (www.litvinenkoinquiry.org).

A detailed analysis of available data on natural concentrations of ${ }^{210} \mathrm{Po}$ in urine (Hodgson 2017) is referred to here in the interpretation of measurements on urine samples taken in the UK during the months following Mr. Litvinenko's death. Use is also made of the data provided by FMBA. Estimates of radiation dose are presented for the two individuals and interpreted in terms of possible risks to health. The efficacy of intramuscular injections of Unithiol in accelerating excretion is also considered on the basis of the data provided.

\section{Methods}

\subsection{Radioactivity measurements}

A sensitive, but relatively rapid, method was developed to handle the large numbers of urine samples analysed during the poisoning incident response (Bailey et al 2008, 2010). It required 2-3 days from receipt of a 24-hour urine sample. The method was adapted from one that is in routine operational use for measurements on environmental samples, e.g. food, and is therefore capable of measuring natural levels of ${ }^{210} \mathrm{Po}$ in many types of sample, including urine. In summary, concentrated nitric acid was added to a 1-litre sample of urine to break down organic matter. The mixture was evaporated slowly (overnight), the residue dissolved in hydrochloric acid, and the ${ }^{210} \mathrm{Po}$ spontaneously deposited onto a silver metal disc for counting using an alpha spectrometer (typically overnight). The minimum detectable activity (MDA) varied between measurements according to the efficiency of the recovery of polonium, which was determined by adding a known amount of a different polonium isotope $\left({ }^{209} \mathrm{Po}\right.$ or $\left.{ }^{208} \mathrm{Po}\right)$ at the start of the process, and measuring the amount present at the end. MDAs of $1-10 \mathrm{mBq} \mathrm{d}^{-1}$ were usually achieved, depending on recovery. Validation checks were performed with five laboratories in the UK and eight in other European countries. Some of these laboratories used different methods for the radiochemical isolation of polonium. The results obtained were all consistent.

\subsection{Estimates of radiation doses}

Bailey et al $(2008,2010)$ developed a methodology for dose assessment of the large number of results of urine measurements becoming available in the first weeks after it had been established that ${ }^{210} \mathrm{Po}$ had been used to poison Mr Litvinenko and, that as a result, a number of places had been contaminated with ${ }^{210} \mathrm{Po}$. Essentially, three categories were identified: (1) urine measurements of $<30 \mathrm{mBq} \mathrm{d}^{-1}$ that were possibly attributable to natural background ${ }^{210} \mathrm{Po}$ levels, (2) effective doses of $<1 \mathrm{mSv}$ estimated by the application of standard conservative assumptions, and (3) effective doses of $>1 \mathrm{mSv}$ estimated using more realistic assumptions applied to individual cases. The estimation of effective dose depended on the use of biokinetic and dosimetric models developed by the International Commission on Radiological Protection (ICRP 1993, 1994a,b, 1996, 2006) and ICRP values of effective dose per $\mathrm{Bq}$ inhaled or ingested. The ICRP models were implemented using the computer codes, IMBA (Birchall et al 2007) and PLEIADES (Fell et al 2007). 
Excretion rates of $\geq 30 \mathrm{mBq} \mathrm{d}{ }^{-1}$ were taken as indicative of possible intake of an artificial source of ${ }^{210} \mathrm{Po}$ (see section 3.1). In all cases of recorded values $\geq 30 \mathrm{mBq}$ $\mathrm{d}^{-1}$, an initial rapid assessment of possible dose was made using a standard set of assumptions that were either realistic (an activity median aerodynamic diameter, AMAD, of $5 \mu \mathrm{m}$, moderate solubility of the aerosol in the respiratory tract (ICRP Type $M)$, or tended to overestimate dose: intake entirely by inhalation rather than ingestion, acute intake on a fixed date as the earliest possible exposure rather than continuing chronic intake, and no subtraction of background levels attributable to natural ${ }^{210} \mathrm{Po}$ (Bailey et al 2008). With these standard assumptions, a set of conversion factors were calculated for estimation of dose from measured activity, dependent only on the duration between the assumed date of intake and the date of sample collection. For all estimates $>1 \mathrm{mSv}$, a more detailed analysis was undertaken, in particular to take account of a more probable balance between intake by inhalation and ingestion (Bailey et al 2008, 2010).

The data provided to the Litvinenko Inquiry by an FMBA Expert Commission in the Russian Federation (reports COM00181001 and COM00182001, www.litvinenkoinquiry.org) included measurements of ${ }^{210} \mathrm{Po}$ activity in urine and faecal samples and estimates of organ doses for two individuals, identified here as $X$ and $Y$. Doses have been reassessed, using ICRP models, together with the systemic biokinetic model developed by Leggett and Eckerman (2001). The data on urinary and faecal excretion have also been used to assess the efficacy of intramuscular injections of Unithiol in accelerating excretion.

\section{Results}

\subsection{Natural background levels of ${ }^{210} \mathrm{Po}$ in urine}

Hodgson (2017) presented a review and analysis of available data on background levels of ${ }^{210} \mathrm{Po}$ in urine. It was determined that 819 measurements could be considered to correspond to natural background levels, excluding a large number of values identified by the authors as potentially due to an artificial source or due to recognised enhancement of dietary intake. Almost 550 measurements were extracted from studies reported in the literature (Black 1956, Globel et al 1966, DeBoeck et al 1971, Bale et al 1975, Okabayashi et al 1975, Juan and Balleos 1976, Holtzman et al 1976, Spencer et al 1977, Clemente et al 1979, Helmkamp et al 1979, Okabayashi et al 1982, Irlweck 1983, Mancini et al 1984, Azeredo \& Lipsztein 1991, Hunt and Allington 1993, Santos et al 1994, Santos et al 1995, Naumann et al 1998, Santos et al 2000, Thomas et al 2001, Schafer and Seitz 2005, Hunt and Rumney 2007, Manickam et al 2010). The additional measurements were contributions of previously unpublished data, acknowledged by Hodgson (2017). The analysis of the measurements gave mean and median values of $14 \mathrm{mBq} \mathrm{d}^{-1}$ and $9 \mathrm{mBq} \mathrm{d}^{-1}$, respectively. Although not conforming statistically to a log-normal distribution, the majority of the measurements were found to be tightly clustered around the mean and median values but with a long asymmetric tail to the distribution. While the overall range was from 0.3 to $170 \mathrm{mBq} \mathrm{d}^{-1}$, more than $90 \%$ of the measurements corresponded to excretion rates less than $30 \mathrm{mBq} \mathrm{d}^{-1}, 95 \%$ were less than $45 \mathrm{mBq}$ $\mathrm{d}^{-1}$ and $99 \%$ less than $70 \mathrm{mBq} \mathrm{d}^{-1}$.

Separate analysis of data for smokers and non-smokers suggested a modest increase in smokers of up to around $5 \mathrm{mBq} \mathrm{d}^{-1}$. Reflecting the importance of dietary differences such as seafood consumption, a marked difference between countries was observed in the range of results (Hodgson 2017). While for most countries, $95 \%$ 
or more of results were below $30 \mathrm{mBq} \mathrm{d}^{-1}$, China and Italy were notable exceptions, with greater than $20 \%$ of values above this level.

\subsection{UK Measurements to assess possible contamination in London during 2006}

The majority of the measurements of excretion rates (total of around 800 ) were below $30 \mathrm{mBq} \mathrm{d}^{-1}$ and were most probably due to natural levels of ${ }^{210} \mathrm{Po}$ in diet, providing no evidence of exposure to an artificial source. The majority of measurements above 30 $\mathrm{mBq} \mathrm{d}^{-1}$ were assessed as corresponding to an effective dose of less than $1 \mathrm{mSv}$ (86 cases identified by Bailey et al 2008, 2010). A total of 36 cases for which more detailed assessments were undertaken had estimated doses within the range of 1 $6 \mathrm{mSv}$ (Bailey et al 2010) or a total of 43 in the range $1-10 \mathrm{mSv}$. Doses in the range $>10 \mathrm{mSv}-100 \mathrm{mSv}$ were recorded for a total of 8 people, mostly staff of one hotel.

\subsection{Russian Federation measurements to assess contamination for two cases}

Assessments of intake and radiation doses have been made for comparison with those reported by FMBA. The results used were measurements on urine, blood and faecal samples taken prior to the administration of Unithiol to increase excretion. Estimates of ${ }^{210} \mathrm{Po}$ intake by individuals $X$ and $Y$ were made separately for each sample taken - urine, faeces and blood. As shown in Tables 1 and 2, estimates vary according to the assumed date and route of intake, and between the samples on which they are based. Values for $X$ average about $4 \mathrm{MBq}$ for either ingestion or inhalation on 1.11.06 and 6-7 MBq for ingestion or inhalation on 16.10.06 (Table 1). Values for $Y$ are estimated to be an order of magnitude lower (Table 2).

Ratios of urinary to faecal excretion $(\mathrm{U} / \mathrm{F})$ for samples measured prior to administration of Unithiol were compared with model predictions to determine whether any conclusions could be drawn regarding route of intake. However, while difference in U/F ratios between inhaled and ingested ${ }^{210} \mathrm{Po}$ would be expected at shorter times after an intake, predicted values corresponding to the times of sample collection showed that there was not a large difference between expected ratios following inhalation and ingestion at these times. It is not possible, therefore, to use the excretion data provided to draw reliable inferences regarding the route(s) of intake in the two cases.

Tables 3 and 4 show estimated organ doses for $X$ calculated using averaged values of intake from Table 1. Assuming intake by ingestion, organ doses are greatest for liver and kidneys at up to around $300 \mathrm{mGy}$ and $400 \mathrm{mGy}$, respectively. Similar doses were estimated for liver and kidneys assuming intake by inhalation and in both cases (ingestion and inhalation), about half of the total organ doses were estimated to have been delivered in the first month after intake and a large proportion of these doses were estimated to have been delivered within three months. Lung doses after inhalation were estimated to be up to around $4 \mathrm{~Gy}$ for intake on 1.11 .06 and $5 \mathrm{~Gy}$ for intake on 16.10.06. 
Table 1. Polonium-210 intake estimates from sample measurements for individual $X^{a}$

\begin{tabular}{|l|c|c|c|c|c|c|}
\hline Sample & \multirow{2}{*}{ Sample date } & \multirow{2}{*}{$\begin{array}{c}\text { Measurement } \\
\text { (Bq/d or Bq) }\end{array}$} & \multicolumn{4}{|c|}{ Estimated intake, MBq } \\
\cline { 4 - 7 } & & & $01 / 11 / 2006$ & $16 / 10 / 2006$ & $01 / 11 / 2006$ & $16 / 10 / 2006$ \\
& & & & & & \\
Urine 1 & & & & & & \\
Urine 2 & $30 / 11 / 2006$ & 550 & 2.9 & 4.6 & 3.0 & 4.4 \\
Urine 3 & 30/11/2006 & 240 & 1.3 & 2.1 & 1.4 & 2.0 \\
Faeces & $29 / 12 / 2006$ & 459 & 2.6 & 4.2 & 2.7 & 4.0 \\
Blood & $29 / 11 / 2006$ & 3750 & 5.7 & 9.3 & 5.4 & 8.3 \\
& & 30000 & 6.9 & 11.1 & 9.8 & 14.3 \\
\hline
\end{tabular}

${ }^{\mathrm{a}}$ Measurements reported by the Federal Medical Biological Agency of the Russian Federation to the Litvinenko Inquiry (www.litvinenkoinquiry.org : COM00181001)

Table 2. Polonium-210 intake estimates from sample measurements for individual $\mathrm{Y}^{\mathrm{a}}$

\begin{tabular}{|l|c|c|c|c|c|c|}
\hline Sample & \multirow{2}{*}{ Sample date } & Measurement & \multicolumn{4}{|c|}{ Estimated intake, MBq } \\
\cline { 4 - 7 } & & & \multicolumn{2}{|c|}{ Ingestion on: } & \multicolumn{2}{|c|}{ Inhalation on: } \\
\hline & & & $01 / 11 / 2006$ & $16 / 10 / 2006$ & $01 / 11 / 2006$ & $16 / 10 / 2006$ \\
& & & & & & \\
Urine 1 & $29 / 11 / 2006$ & 31 & 0.2 & 0.3 & 0.2 & 0.3 \\
Urine 2 & $30 / 11 / 2006$ & 53 & 0.3 & 0.5 & 0.3 & 0.4 \\
Faeces & $29 / 11 / 2006$ & 622 & 0.9 & 1.5 & 0.9 & 1.4 \\
Blood 1 & $28 / 11 / 2006$ & 2500 & 0.6 & 0.9 & 0.8 & 1.2 \\
Blood 2 & $29 / 11 / 2006$ & 2200 & 0.5 & 0.8 & 0.7 & 1.1 \\
& & & & & & \\
\hline
\end{tabular}

${ }^{\mathrm{a}}$ Measurements reported by the Federal Medical Biological Agency of the Russian Federation to the Litvinenko Inquiry (www.litvinenkoinquiry.org : COM00182001)

Table 3. Estimated absorbed doses to organs for $\mathrm{X}$, assuming ingestion of ${ }^{210} \mathrm{Po}$

\begin{tabular}{|l|c|c|c|c|c|c|}
\hline $\begin{array}{l}\text { Assumed } \\
\text { day of } \\
\text { intake }\end{array}$ & \multirow{2}{*}{$\begin{array}{l}\text { Integration } \\
\text { period }\end{array}$} & \multicolumn{5}{|c|}{ Organ dose, mGy } \\
\cline { 3 - 7 } & & RBM $^{\text {a }}$ & Liver & Kidneys & Spleen & Lungs \\
\cline { 3 - 7 } 1.11 .06 & $30 \mathrm{~d}$ & 19 & 98 & 150 & 64 & 4 \\
& $100 \mathrm{~d}$ & 33 & 160 & 240 & 100 & 7 \\
& Total & 37 & 170 & 260 & 110 & 7 \\
& & & & & & \\
& $30 \mathrm{~d}$ & 30 & 160 & 240 & 100 & 6 \\
& $100 \mathrm{~d}$ & 53 & 250 & 380 & 170 & 11 \\
& Total & 60 & 270 & 420 & 180 & 12 \\
\hline
\end{tabular}

${ }^{\mathrm{a}} \mathrm{RBM}$ : Red Bone Marrow 
Table 4. Estimated absorbed doses to organs for $\mathrm{X}$, assuming inhalation of ${ }^{210} \mathrm{Po}$

\begin{tabular}{|l|c|c|c|c|c|c|}
\hline $\begin{array}{l}\text { Assumed } \\
\text { day of } \\
\text { intake }\end{array}$ & \multirow{2}{*}{$\begin{array}{l}\text { Integration } \\
\text { period }\end{array}$} & \multicolumn{5}{|c|}{ Organ dose, mGy } \\
\cline { 3 - 7 } & & RBM & Liver & Kidneys & Spleen & Lungs \\
\cline { 3 - 7 } 1.11 .06 & $30 \mathrm{~d}$ & 14 & 74 & 150 & 48 & 2400 \\
& $100 \mathrm{~d}$ & 27 & 130 & 250 & 86 & 3500 \\
& Total & 34 & 150 & 290 & 100 & 3700 \\
& & & & & & \\
& $30 \mathrm{~d}$ & 21 & 110 & 230 & 71 & 3600 \\
& $100 \mathrm{~d}$ & 41 & 190 & 370 & 130 & 5200 \\
& Total & 50 & 230 & 430 & 150 & 5500 \\
\hline
\end{tabular}

${ }^{\mathrm{a}} \mathrm{RBM}$ : Red Bone Marrow

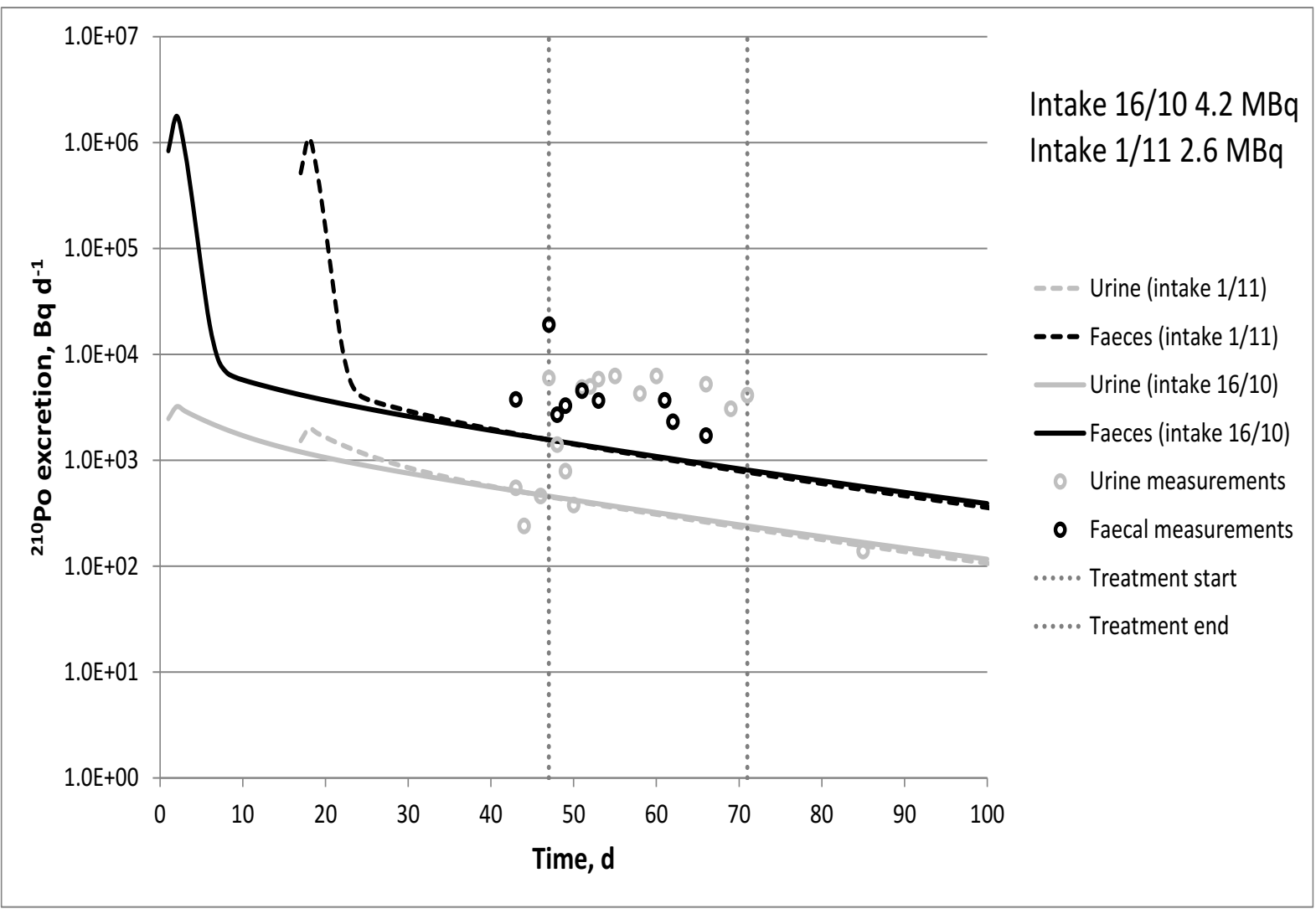

Figure 1. Urinary and faecal excretion of ${ }^{210} \mathrm{Po}$ for $\mathrm{X}$, comparing modelled excretion for inhalation or ingestion based on intake corresponding to urine sample 3 (Table 1), and measured values during Unithiol treatment 
Table 5. Assessment of the efficacy of Unithiol treatment of $X$ by comparison of predicted excretion of ${ }^{210} \mathrm{Po}$ without treatment to measured excretion following administration of Unithiol

\begin{tabular}{|c|c|c|c|c|c|}
\hline Sample & $\begin{array}{c}\text { Assumed } \\
\text { date of intake }\end{array}$ & Model $^{\mathrm{a}}$ & $\begin{array}{c}\text { Predicted } \\
\text { excretion without } \\
\text { treatment } \mathrm{t}^{\mathrm{b}}, \mathrm{kBq}\end{array}$ & $\begin{array}{c}\text { Observed } \\
\text { excretion with } \\
\text { treatment }^{\mathrm{b}}, \mathrm{kBq}\end{array}$ & $\begin{array}{c}\text { Actual/ } \\
\text { predicted }\end{array}$ \\
\hline \multirow[t]{8}{*}{ Urine } & 16/10/2006 & U1 & 9.2 & 116 & 12.6 \\
\hline & 01/11/2006 & U1 & 9.1 & 116 & 12.8 \\
\hline & 16/10/2006 & U2 & 4.2 & 116 & 27.6 \\
\hline & 01/11/2006 & U2 & 4.1 & 116 & 28.5 \\
\hline & 16/10/2006 & U3 & 8.4 & 116 & 13.8 \\
\hline & 01/11/2006 & U3 & 8.1 & 116 & 14.2 \\
\hline & 16/10/2006 & $\mathrm{F}$ & 18.6 & 116 & 6.2 \\
\hline & $01 / 11 / 2006$ & $F$ & 17.8 & 116 & 6.5 \\
\hline \multirow[t]{8}{*}{ Faeces } & $16 / 10 / 2006$ & U1 & 26.5 & 80.3 & 3.0 \\
\hline & 01/11/2006 & U1 & 26.5 & 80.3 & 3.0 \\
\hline & 16/10/2006 & U2 & 12.1 & 80.3 & 6.6 \\
\hline & $01 / 11 / 2006$ & U2 & 11.9 & 80.3 & 6.8 \\
\hline & $16 / 10 / 2006$ & U3 & 24.2 & 80.3 & 3.3 \\
\hline & $01 / 11 / 2006$ & U3 & 23.7 & 80.3 & 3.4 \\
\hline & 16/10/2006 & $\mathrm{F}$ & 53.7 & 80.3 & 1.5 \\
\hline & 01/11/2006 & $\mathrm{F}$ & 52.0 & 80.3 & 1.5 \\
\hline
\end{tabular}

${ }^{a}$ Model: the measurement in Table 1 on which estimates of intake and consequent urinary and faecal excretion were made, without consideration of the effect of Unithiol

${ }^{\mathrm{b}}$ Considering only the treatment period

\subsection{Effectiveness of Unithiol treatment to increase ${ }^{210} \mathrm{Po}$ excretion}

Figure 1 illustrates analyses undertaken of the effect of Unithiol in enhancing excretion of ${ }^{210} \mathrm{Po}$ in the case of $\mathrm{X}$. FMBA physicians administered Unithiol intramuscularly over an extended period from $2^{\text {nd }}$ December 2006 until $X$ was discharged from hospital on $28^{\text {th }}$ December 2006. Figure 1 shows modelled excretion curves for both urinary and faecal excretion of ${ }^{210} \mathrm{Po}$, for the two assumed times of intake, based on urine sample 3 taken on $2^{\text {nd }}$ December (Table 1) before Unithiol treatment was started. Thus, the curves in Figure 1 show estimates of the normal 
pattern of excretion without chelation therapy and the points are the measured excretion values.

Table 5 shows the results obtained by separate consideration of each intake estimate provided in Table 1, comparing model predictions of ${ }^{210} \mathrm{Po}$ excretion in the absence of treatment and estimates of actual excretion as shown by measurements during the period of treatment. The possibility that the effects of Unithiol persisted beyond the treatment window was not pursued. As measurements were not available for every day during the treatment period, estimates of excretion on these days were interpolated using a cubic spline. The data indicate that urinary excretion was increased during the treatment period by an average of a factor of 15 and faecal excretion was increased by a factor of 4 . Thus, it appears that continued intramuscular administration of Unithiol is effective in enhancing excretion. However, mainly because of the delay between the assumed time of intake and the commencement of treatment, the overall effect on retention and the averted dose attributable to treatment is modest at less than 10\% (probably nearer $5 \%$ ).

\section{Discussion}

Mr Alexander Litvinenko died in a London hospital on $23^{\text {rd }}$ November 2006, after having ingested an amount of ${ }^{210} \mathrm{Po}$ on $1^{\text {st }}$ November 2006 , estimated to be around 4 GBq (Nathwani et al 2016, Harrison et al 2017). There is evidence of an earlier intake during October 2006 but at a substantially lower level that does not affect the interpretation of the fatal consequences of the intake on $1^{\text {st }}$ November (Harrison et al 2017).

An analysis of over 800 measurements of natural background ${ }^{210} \mathrm{Po}$ in urine gave mean and median excretion rates of $13.8 \mathrm{mBq} \mathrm{d}^{-1}$ and $9.3 \mathrm{mBq} \mathrm{d}^{-1}$, respectively (Hodgson 2017). Consideration of results for individual countries indicated that UK values are generally lower, with a median of around $6 \mathrm{mBq} \mathrm{d}^{-1}$. The amount ingested by $\mathrm{Mr}$ Litvinenko was therefore about $10^{12}$ times greater than natural daily intake levels.

Polonium-210 was not established as the cause of Mr Litvinenko's illness until the day of his death. From that time, an intensive survey of contamination of key London sites was initiated, together with a large programme of monitoring of people who may have become contaminated (Bailey et al 2008, 2010, Maguire et al 2010, Shaw et al 2010). Based on an early and rapid review of natural background levels of ${ }^{210} \mathrm{Po}$ in urine, a value of $30 \mathrm{mBq} \mathrm{d}^{-1}$ was chosen as an excretion rate above which intake was unlikely to be wholly attributable to natural dietary sources. The extensive analysis by Hodgson (2017) showed that while there was a very large range in individual values of from 0.3 to $170 \mathrm{mBq} \mathrm{d}{ }^{-1}$, more than $90 \%$ of the measurements were less than $30 \mathrm{mBq} \mathrm{d}^{-1}$, supporting the early judgment. Separate analyses of data for individual countries showed that $95 \%$ or more of results were below $30 \mathrm{mBq} \mathrm{d}^{-1}$ in most cases, including the UK, but that China and Italy were notable exceptions for which more than $20 \%$ of values were above this level.

More than 800 urine samples were analysed as part of the investigation of possible contamination resulting from direct contact with Mr Litvinenko or proximity during key events. The majority of the measured excretion rates were below $30 \mathrm{mBq} \mathrm{d}^{-1}$, providing no evidence of exposure to an artificial source. The majority of measurements above $30 \mathrm{mBq} \mathrm{d}{ }^{-1}$ were assessed as corresponding to an effective dose of less than $1 \mathrm{mSv}$ (86 cases identified by Bailey et al 2008, 2010). A total of 43 individuals for whom more detailed assessments were undertaken had assessed 
effective doses in the range $1-10 \mathrm{mSv}$. Effective doses in the range $>10 \mathrm{mSv}-$ $100 \mathrm{mSv}$ were recorded for a total of 8 people, mostly staff of one hotel.

The Litvinenko Inquiry was provided with reports on two additional contaminated individuals by an Expert Commission of the Federal Medical and Biological Agency (FMBA) of the Russian Federation (reports COM00181001 and COM00182001, www.litvinenkoinquiry.org). The FMBA reports included estimates of intake and organ doses based on measurements of urinary and faecal excretion of ${ }^{210} \mathrm{Po}$ and ${ }^{210} \mathrm{Po}$ concentrations in blood samples. The data are reassessed in this paper, with essentially similar results. The two individuals are referred to here as $X$ and $Y$. Estimates of intake by $X$ averaged about $4 \mathrm{MBq}$ for either ingestion or inhalation on 1.11.06 and $6-7 \mathrm{MBq}$ for ingestion or inhalation on 16.10.06. Values for $Y$ were estimated to be an order of magnitude lower. Assuming intake by ingestion, estimated organ doses for $X$ reached maximum values of up to around $300 \mathrm{mGy}$ for liver and $400 \mathrm{mGy}$ for kidneys. Similar doses were estimated for liver and kidneys assuming intake by inhalation and in both cases (ingestion and inhalation), about half of the total organ doses were estimated to have been delivered in the first month after intake and a large proportion of these doses were estimated to have been delivered within three months. Assuming intake by inhalation, lung doses were estimated to be up to around $4-5 \mathrm{~Gy}$. Estimated effective doses were around $1.5 \mathrm{~Sv}$ for $\mathrm{X}$ and $200 \mathrm{mSv}$ for $\mathrm{Y}$, assuming intake solely by ingestion, 9 Sv and 1 Sv, respectively, assuming intake by inhalation, and around $5 \mathrm{~Sv}$ and $800 \mathrm{mSv}$, respectively, assuming intake by both routes (1:1).

The chelating agent, Unithiol, was administered intramuscularly to both individuals during their time in hospital. Analysis of excretion rates for $\mathrm{X}$ indicated that urinary excretion was effectively increased during the treatment period by an average of a factor of 15 and faecal excretion was increased by a factor of 4 . However, mainly because of the delay between the assumed time of intake and the commencement of treatment, the overall effect on retention and the averted dose attributable to treatment appeared to be less than $10 \%$ and probably nearer $5 \%$. For a short commentary on the use of chelating agents to enhance excretion of ${ }^{210} \mathrm{Po}$, see Jefferson et al (2009).

The very different levels of ${ }^{210} \mathrm{Po}$ intake experienced, ranging from the large intake suffered by Mr Litvinenko on $1^{\text {st }}$ November 2006 to the natural background levels to which we are all exposed daily, is illustrative of the range of associated risks to health, from the certainty of death at the highest doses to the possibility of a very low and uncertain risk of cancer associated with the lowest doses.

Mr Litvinenko died three weeks after ingestion of an amount of ${ }^{210} \mathrm{Po}$ estimated as around $4 \mathrm{GBq}$ ( $400 \mathrm{MBq}$ absorbed to blood). Death was the inevitable outcome of the radiation doses estimated to have been received by Mr. Litvinenko's red bone marrow, kidneys and liver (Nathwani et al 2016, Harrison et al 2017). Bone marrow failure is likely to have been an important contributory cause of death occurring within a few weeks of intake, as a component of multiple organ failure.

Autoradiography of hair samples from Mr Litvinenko provided evidence of an earlier intake of ${ }^{210} \mathrm{Po}$ during October 2006 at a level of around $1 \%$ of the major intake on $1^{\text {st }}$ November. As discussed by Harrison et al (2017), it is possible in principle that an intake by ingestion at this $1 \%$ level, of around $40 \mathrm{MBq}$ ( $4 \mathrm{MBq}$ absorbed to blood), could have proved fatal over a period of months or years, assuming that no medical intervention was instituted. Animal data reviewed by Harrison et al (2007) showed death occurring over a period of a few years as a result primarily of kidney damage at doses averaging around $1.5 \mathrm{~Gy}$, which compares with an estimated kidney dose to 
Mr Litvinenko from the first intake, if the second intake had not occurred, of a maximum of approaching 3 Gy.

The FMBA of the Russian Federation provided data to the Litvinenko Inquiry on two individuals with substantial ${ }^{210} \mathrm{Po}$ contamination (reports COM00181001 and COM00182001, www.litvinenkoinquiry.org). Estimates of intake of ${ }^{210} \mathrm{Po}$ by the individual with the greatest contamination are about 1000 times less than estimated for the major intake by Mr Litvinenko, around $4-7 \mathrm{MBq}(400-700 \mathrm{kBq}$ absorbed to blood), depending on when the intake(s) occurred. Estimated organ doses were generally below levels that would be expected to cause acute clinically observable damage. Maximum estimates of kidney doses were about $400 \mathrm{mGy}$, below thresholds for irreversible acute damage. Lung doses could have been as high as $2-$ 5 Gy if intake had been solely by inhalation and the inhaled chemical form had been moderately soluble in the respiratory tract (ICRP Type M). It is possible that such high doses to the lungs could result in clinically observable short-term effects. However, FMBA clinicians observed that no pathological change in lungs were detected (COM00181001 www.litvinenkoinquiry.org).

Below threshold doses for acute deterministic effects, the concern is increased risk of stochastic effects, principally cancer. Effective dose is a risk-adjusted dosimetric quantity that is used for protection purposes and the control of exposures in relation to stochastic risks (ICRP 2007). Although not intended for the purpose of estimating risks of exposures, particularly for individuals, it can be used with caution to provide a rough indication of risk. Effective dose (Sv) is calculated as the doubly-weighted sum of absorbed doses (Gy) to organs and tissues, first using radiation weighting factors to correct for the relative biological effectiveness (RBE) of different radiation types (e.g. alpha particles compared with gamma rays) in relation to stochastic effects, and second, tissue weighting factors to represent fractional contributions of organs/tissues to overall detriment from stochastic effects. The nominal risk coefficient applied by ICRP to fatal cancer is 5\% per Sv (ICRP 2007).

Using the ICRP nominal risk coefficient as an approximate indicator of risk in the case of $\mathrm{X}$, estimates of effective dose of around $5 \mathrm{~Sv}$, depending in particular on the assumed route of intake (ingestion or inhalation), correspond to a lifetime risk of fatal cancer of around $25 \%$, applying as the estimated mortality in a population of people exposed at this level. In comparison, incidence rates in developed countries are around $40 \%$, with overall fatalities accounting for very roughly half of cases, although incidence and survivability vary substantially between cancer types. A $25 \%$ increase in the risk of fatal cancer represents a substantial increase on background rates, approximately doubling lifetime risk. It should be noted that the ICRP risk coefficient of $5 \%$ per Sv (ICRP 2007) is intended to apply to low dose and dose rate exposures and is therefore of questionable applicability to the high organ doses in this particular case. However, while this consideration might lead to use of a somewhat higher value by up to a factor of two, it is also arguable that the use of a radiation weighting factor of 20 for alpha particles is generally conservative (Harrison and Muirhead 2003, Marsh and Harrison 2014). Ingestion seems a more likely route of intake than inhalation for both $X$ and $Y$, leading to lower estimates of lung dose and effective dose (see above), although the possibility of airborne contamination cannot be excluded.

To obtain better estimates of risks of radiation-induced cancer, rather than using effective dose to provide an approximate indication of risk, requires the use of age-, sex- and population- specific risk factors for individual cancer types applied to organ absorbed doses (Gy), making due allowance for RBE of alpha particles relative to gamma rays for each cancer type. Such detailed analyses are beyond the scope of 
this paper, but scoping calculations showed similar overall results when considering organ-specific risks, although with lower risks when considering age, sex and population (about 15\% fatal cancer risk compared with about $25 \%$ ).

In general terms, doses of around $100 \mathrm{mSv}$ represent the limit of reliable direct epidemiological observations of statistically significant increases in cancer rates in studies of exposed populations (Boice 2014a,b, UNSCEAR 2012a,b). In addition to the uncertainties associated with the risk factors derived from such studies, applying largely to external exposures to gamma rays, there is the additional uncertainty in the present context of their application to internal ${ }^{210} \mathrm{Po}$ exposures for which there is no direct information on cancer induction. Support for the assumption of equivalence of external radiation exposures and internal alpha particle irradiation, once account is taken for RBE, includes quantitative comparisons with risk factors for alpha particle emitting nuclides, notably lung cancer associated with inhalation of radon-222 and its progeny, but also inhaled plutonium-239, and leukaemia, liver and bone cancer induction by other nuclides (Harrison and Muirhead 2003, Marsh and Harrison 2014). These comparisons and available experimental evidence support the assumption that an estimated effective dose of the order of $100 \mathrm{mSv}$ from ${ }^{210} \mathrm{Po}$ is associated with a risk of cancer (around $0.5 \%$ ) that may in principle be discernible in studies of large population groups but corresponds to a small additional risk to individuals. The large number of incident cancers in such a group would be very largely attributable to causes other than radiation (> 95\%).

Effective doses of a few 10s of mSv and less are generally below levels for which there is direct evidence of harm in human populations. Studies at such doses have focussed on children because of their generally greater sensitivity to radiationinduced cancer and significant effects have been reported (Pearce et al 2012, Mathews at al 2013, Kendall et al 2013). However, caution is required in the interpretation of positive results for CT examinations (Pearce et al 2012, Mathews at al 2013) because of the potential for reverse causation (UNSCEAR 2013, Walsh et al 2014). Preliminary findings of an association between natural background gamma radiation and childhood leukaemia in Britain (Kendall et al 2013) await further study and confirmation. While it is important to pursue sources of direct epidemiological evidence of radiation effects in humans at low doses and dose rates (Boice 2014a,b), it will always be the case that estimates of risk at very low doses will depend on mechanistic understanding and projection of risk estimates derived at higher doses. The protection system recommended by ICRP adopts a linear non-threshold (LNT) dose response relationship in the control of exposures down to very low levels of dose. While this is a pragmatic and convenient approach that allows the addition of doses of different magnitude and different types, it is also difficult to challenge as the most plausible approach on the basis of our current scientific understanding of the mechanisms of radiation action (Preston et al 2003, UNSCEAR 2012c). The experimental data and theoretical considerations do not provide firm conclusions regarding deviation from linearity. While this issue is of critical importance to ensure that protection at low doses is sufficient but not unduly restrictive, in the present context of one-off exposures to ${ }^{210} \mathrm{Po}$, the inferred risk to health associated with doses of a few 10 s of $\mathrm{mSv}$ and less should be regarded as very small and not of concern.

\section{References}

Azeredo AF and Lipsztein JL (1991) Po-210 Excretion in Urine: A Comparison of an Occupational Exposed Group and a Control. Radiat. Prot. Dosim. 36, 51-54. 
Bailey M, Birchall A, Bishop L, Etherington G, Evans B, Fraser G, Gross R, Maguire $\mathrm{H}$, Shaw K and Wilkins B (2008) Individual Monitoring Conducted by the Health Protection Agency in the London Polonium-210 Incident. Proc. $12^{\text {th }}$ International Radiation Protection Association Meeting, Buenos Aires, 19-24 October 2008.

Bailey MR, Birchall A, Etherington G, Fraser G, Wilkins BT, Bessa Y, Bishop L, Brown J, Dorrian M-D, Ewer LW, Fell TP, Ham GJ, Hammond DJ, Forrester S, Hodgson A, Howarth C, Ibrahimi Z-F, Maguire H, Marsh J, Phipps AW, Puncher M, Ruggles R, Shutt A, Smith JRH, Turbitt D, Youngman MJ and Wilding D (2010) Individual Monitoring Conducted by the Health Protection Agency in the London Polonium-210 Incident. HPA-RPD-067.

Bale WF, Helmkamp RW, Hrynyszyn V and Contreras MA (1975) The determination of Po-210 in urine. Health Physics 29, 663-671.

Birchall A, Puncher M, Marsh JW, Davis K, Bailey MR, Jarvis NS, Peach AD, Dorrian, MD and James AC (2007) IMBA professional plus: a flexible approach to internal dosimetry. Proc. European Workshop on Individual Monitoring of lonising Radiation, IM 2005, Vienna, April 2005. Radiat. Prot. Dosim. 125, 194-197.

Black SC (1956) Low Level Polonium Determination of Tissue and Urine - PhD thesis. Technical Report - OSTI ID: 4338659.

Boice JD, Jr. (2014a) Uncertainties in studies of low statistical power (editorial) J.Radiol. Prot. 30, 115-20.

Boice JD, Jr. (2014b) The importance of radiation worker studies (editorial) J.Radiol Prot. 34, E7-E12.

Clemente GF, Santori G, Renzetti A and Bachvarova AK (1980) Valutazione della esposizione dovuta al $\mathrm{Pb} 210-\mathrm{Po} 210$ nella popolazione italiana. CNEA report, RT/PROT(79)6.

De Boeck R, Adams F and Hoste J (1971) The Determination of Po-210 in Urine. Health Phys 20, 403-407.

Fell, TP, Phipps AW and Smith TJ (2007) The internal dosimetry code PLEIADES. Radiat. Prot. Dosim. 124, 327-38.

Glöbel B, Muth H and Oberhausen E (1966) Aufnahmen und Ausscheidung der naturlichen Radionuklide ${ }^{210} \mathrm{~Pb}$ und ${ }^{210} \mathrm{Po}$ durch den Menschen, Strahlentherapie 131, 218-226.

Harrison JD, Leggett RW, Lloyd DC, Phipps AW and Scott BR (2007) Polonium-210 as a poison. J. Radiol. Prot. 27, 17-40.

Harrison JD, Leggett RW, Lloyd DC, Puncher M, Youngman MJ and Fell TP (2017) The polonium-210 poisoning of Mr Alexander Litvinenko. J. Radiol. Prot. (in press).

Harrison JD and Muirhead CR (2003) Quantitative comparisons of cancer induction in humans by internally deposited radionuclides and external radiation. Int. J. Radiat. Biol. 79, 1-13. 
Helmkamp RW, Bale WF and Hrynyszyn V (1979) The Determination of Po-210 and Bi-210 in Human Urine by Direct Extraction on Nickel. Int. J. Applied Radiation and Isotopes 30, 237-246.

Hodgson A (2017) Natural background levels of polonium-210 in urine. J. Radiol. Prot. (submitted).

Holtzman RB, Spencer H, Ilcewicz FH and Kramer L (1976) Variability of Excretion Rates of Pb-210 and Po-210 of Humans at Environmental Levels. Proc 10th Midyear Topical Symp of the Health Physics Society, 1976.

Hunt GJ, and Allington DJ (1993) Absorption of environmental Po-210 by the human gut. J. Radiol. Prot. 13, 119-126.

Hunt GJ and Rumney HS (2007) The human alimentary tract transfer and body retention of environmental polonium-210. J. Radiol. Prot. 27, 405-426.

ICRP (1993) Age-dependent doses to members of the public from intakes of radionuclides: Part 2. Ingestion dose coefficients. Ann. ICRP 23 (3/4). Elsevier Science Ltd., Oxford.

ICRP (1994a) Human Respiratory Tract Model for Radiological Protection. ICRP Publication 66. Ann. ICRP 24 (1-3). Elsevier Science Ltd., Oxford.

ICRP (1994b) Dose Coefficients for Intake of Radionuclides by Workers. ICRP Publication 68. Ann. ICRP 24 (4). Elsevier Science Ltd., Oxford.

ICRP (1996) Age-dependent Doses to Members of the Public from Intake of Radionuclides Part 5: Compilation of Ingestion and Inhalation Dose Coefficients. ICRP Publication 72. Ann. ICRP 26 (1). Elsevier Science Ltd, Oxford.

ICRP (2006) Human Alimentary Tract Model for Radiological Protection. ICRP Publication 100. Ann. ICRP. 36 (1-2). Elsevier Science Ltd., Oxford.

ICRP (2007) The 2007 Recommendations of the International Commission on Radiological Protection. ICRP Publication 103. Ann ICRP 37(2-4).

Irlweck, K (1983) Untersuchungen uber die innere Strahlenbelastung des Menchen durch Polonium-210. Mitt. Osterr. Sanitatsverwalt. 83, 3-8 (1982). Austrian research Centrer. Siebersdorf, OEFZS Rep. No 4193.

Jefferson RD, Goans RE, Blain PG and Thomas SHL (2009) Diagnosis and treatment of polonium poisoning. Clinical Toxicology 47, 379-392.

Juan NB and Ballelos E (1976) The determination of polonium in urine of Filipino non-smokers and smokers. Mar 1976. 4 p, MF available from INIS under the Report Number, PAEC(D)-76004.

Kendall, GM, Little, MP, Wakeford R, Bunch KJ, Miles JC, Vincent TJ, Meara JR and Murphy MF (2013) A record-based case-control study of natural background radiation and the incidence of childhood leukaemia and other cancers in Great Britain during 1980-2006. Leukaemia 27, 3-9. 
Maguire H, Fraser G, Croft J, Bailey M, Tattersall P, Morrey M, Turbitt D, Ruggles R, Bishop L, Giraudon I, Walsh B, Evans B, Morgan O, Clark M, Lightfoot N, Gilmour R, Gross R, Cox R, and Troop P. (2010) Assessing public health risk in the London polonium-210 incident, 2006. Public Health 124, 313-318.

Mancini L, Renzetti A and Santori G (1984) Livelli di Polonio-210 Nelle Urine di Alcuni Gruppi Della Popolazione Italiana. ENEA report, RT/PAS/84/13, October 1984.

Manickam E, Sdraulig S and O'Brien R (2010) An Improved and Rapid Radiochemical Method for the Determination of Polonium-210 in Urine. Aust. J. Chem, 63, 38-46.

Marsh JW, Harrison JD, Laurier D, Birchall A, Blanchardon E, Paquet $F$ and Timarche M (2014) Doses and lung cancer risks from exposure to radon and plutonium. Int. J. Radiat. Biol. 90, 1080-7.

Mathews JD et al (2013) Cancer risk in 680000 people exposed to computed tomography scans in childhood or adolescence: data linkage study of 11 million Australians. Brit. Med. J. 2346, f2360.

Nathwani AC, Down JF, Goldstone J, Yassin J, Dargan P, Virches A, Gent RN, Lloyd $\mathrm{D}$ and Harrison JD. Polonium-210, a deadly poison. The Lancet (submitted).

Naumann M, Hanisch K and Hartmann M (1998) Levels of natural radionuclides in human excreta in the Berlin area. Radiat. Prot. Dosim. 79, 197-200.

Okabayashi H (1982) A Study on the Excretion of Pb-210 and Po-210. J. Radiat. Res. 23, 242-252.

Pearce MS et al (2012) Radiation exposure from CT scans in childhood and subsequent risk of leukaemia and brain tumours: a retrospective cohort study. Lancet 380, 499-505.

Preston RJ (2003) The LNT is the best we can do - today. J. Radiol. Prot. 23, 263-8.

Santos PL, Gouvea RC, Dutra IR (1994) Concentrations of ${ }^{210} \mathrm{~Pb}$ and ${ }^{210} \mathrm{Po}$ in hair and urine of workers, of the uranium mine at Pocos de Caldas (Brazil). Sci. Total Env. 148, 61-65.

Santos PL, Gouvea RC and Dutra IR (1995) Human occupational radioactive contamination from the use of phosphated fertilizers. Sci.Total Env. 162, 19-22.

Schafer I and Seitz G (2005) Ermittlung der Zufuhr von natürlichen Radionukliden der ranzerfallsreihe (230Th, 226Ra, 210Pb, 210Po) bei Personen aus der Bevölkerung,in belasteten Gebieten und Wohnungen und an NORM-Arbeitsplätzendurch Ausscheidungsanalyse. Bundesministerium für Umwelt, Naturschutz und Reaktorsicherheit Bundesamt für Strahlenschutz St.Sch.-Nr.4280.

Shaw K, Anders K, Olowokure B, Fraser G, Maguire H, Bailey MR, Smith JRH, Frossell S, Yap K, Evans B. (2010) The international follow-up of individuals potentiallyexposed to polonium-210 in London 2006. Public Health 124, 319-325. 
Spencer H, Holtzman RB, Kramer L, Ilcewicz FH (1977) Metabolic balances of ${ }^{210} \mathrm{~Pb}$ and ${ }^{210} \mathrm{Po}$ at natural levels. Radiat. Res. 69, 166-184.

Thomas PA, Fisenne I, Chorney D, Baweja AS and Tracy BL (2001). Human absorption and retention of Po-210 from Caribou meat. Radiat. Prot. Dosim. 97, 241250.

UNSCEAR (2012a) United Nations Scientific Committee on the Effects of Atomic Radiation. Sources, effects and risk of ionizing radiation. Annex A. Attributing health effects to ionizing radiation exposure and inferring risk. United Nations, Vienna.

UNSCEAR (2012b) United Nations Scientific Committee on the Effects of Atomic Radiation. Sources, effects and risk of ionizing radiation. Annex B. Uncertainties in risk estimates for radiation-induced cancer. United Nations, Vienna.

UNSCEAR (2012c) United Nations Scientific Committee on the Effects of Atomic Radiation. Biological Mechanisms of Radiation Actions at Low Doses. A white paper to guide the Scientific Committee's future programme of work. United Nations, Vienna.

UNSCEAR (2013) United Nations Scientific Committee on the Effects of Atomic Radiation. Sources, effects and risk of ionizing radiation. Vol II, Annex B. Effects of radiation exposure in children. United Nations, Vienna.

Walsh L, Shore R, Auvinen A, Jung T and Wakeford R (2014) Risks from CT scans what do recent studies tell us? (editorial) J. Radiol. Prot. 34, E1-E5. 